\title{
Screening Power: Harry Truman and the Nuclear Leviathan
}

Harry Truman's succession to the United States presidency upon Franklin Roosevelt's death in 1945 thrust an obscure and inexperienced politician into the center of one of the 20th century's most critical historical moment: the final months of World War II, as the United States was preparing to deploy nuclear weapons for the first time. Truman's clear unequalness (in both image and substance) to the tasks at hand, in juxtaposition with the epic scale of the tasks themselves, provides a unique exposure of the illusory nature of presidential authority in the Nuclear Age. Using Thomas Hobbes's Leviathan as a means of delineating the theory and image of political sovereignty, this essay examines three distinct moments from the early days of Truman's administration that serve to elucidate the absence of presidential power and control that continues to this day to underlie the media apparatus that defines the American presidency.

Keywords

AESTHETICS

POLITICS

COLD WAR

U.S. PRESIDENTS

NUCLEAR BOMB

CINEMA

LEVIATHAN

Date of reception: $27 / 04 / 2018$

Date of acceptance: 15/09/2018

Isabelle Freda Assistant Professor of Film Studies in the Lawrence Herbert School of Communication at Hofstra University. Her recent work has appeared in NECSUS/European Journal of Media Studies, International Journal of Contemporary Iraqi Studies, and New Review of Film and Television Studies. She is the author of the forthcoming Screening Biopolitics: The Cold War, the Modern Presidency, and the Bomb. 


\section{Introduction}

Screens both reveal and hide, as Freud (1899) has shown us - a lesson taken up by film theory for the subtlety of its approach to screen representation: as both present and absent, thereby revealing that the image, regardless of its signifying force, can mark an abyss as much as fill one.' It is in this spirit that I approach three inter-related moments that together comprise a crisis in the representation of power: three moments in history across the critical years from the use of nuclear weapons against the hundreds of thousands of Japanese residents of Hiroshima and Nagasaki and the beginning of the "Cold War", what Sheldon Wolin has called the transition from the "power imaginary" of World War II to the "new power imaginary and its totalizing categories" of the Cold War (WOLIN, 2008: 28).

The figure at the center of this story - but not its protagonist - is American president Harry S. Truman, the lackluster heir to Franklin D. Roosevelt's dozen years of political stardom. Thrust onto the world stage only months after his election as Vice President, Truman's unlikely role as the first modern president after FDR and, even more, the first to use the nuclear weapon that had been hidden within the bowels of the top-secret Manhattan project for five years - Truman's story is one available for analysis using the tools of Cinema Studies and those deriving from the critique of the theory of the Leviathan, that figure of Thomas Hobbes which is both a theory and an image of political sovereignty.

This is the story of the screening of this president during the transition to a permanent state of war, a transition that was uniquely revelatory of the new power dynamics of the Cold War, the new power imaginary of the nuclear national security state formalized by NSC $68 .{ }^{2}$ It is a tale told in three acts of the tensions which emerged in this liminal moment in which power began to escape its localization in the figure of popular sovereignty, the president.

Our three moments, in three different media: first, the epistolary portrait of Truman's "decision" to deploy the nuclear bomb on the city of Hiroshima; second, the stunning drawn portrait of Truman on the cover of Time's 1945 "Man of the Year" issue; and finally, the cinematic portrait conveyed in the 1947 MGM film The Beginning or the End (directed by Norman Taurog), which is unique for its effort to incorporate a sitting president into a biopic-like narrative about the decision to use the nuclear bomb.

\section{Part I: The Leviathan: Theory and Practice}

This brief analysis seeks to begin to pry open the crypt of power in the nuclear age through an examination of the origins of the modern presidency in the United States - its "official aesthetics", if you will - at the dawn of the nuclear age. The screening of the president is best approached using the toolkit developed in Cinema Studies or Screen Studies, as its sensitivity to both spectacle and reception provides an antidote to the disciplinary blinkers of those usually charged with studying the presidency - and power.

During the past thirty years, the figure posited in Thomas Hobbes's Leviathan has emerged again and again in the work of some of our most powerful thinkers, from Michel Foucault to Giorgio Agamben, Jacques Derrida, and Eric Santner ${ }^{3}$ as a figure that is both a theory about power and a model of its application.

Most discussions about the presidency, in whatever arena or discipline, whether academic or not, subscribe - either implicitly or explicitly - to the Hobbesian figure 
of the Leviathan, a figure that is also a philosophy, or theory: the monarch/ leader enjoys a contractual right to govern, presumably to protect the populace. Because this theory concerns itself only with the narrowly circumscribed question of the legitimacy of power in a juridical or legal sense, it obscures the ways in which actual power is dispersed throughout the social body. ${ }^{4}$ The discourse of the Leviathan functions to keep the sovereign front and center in ways analogous to that of the film star embedded within a narrative that improbably, yet satisfyingly, appears to arise from and support the protagonist's prowess, authority and/ or power. "Power" masquerades across media, still or moving image regardless. Whether it appears as a royal or a republican body, it wears its face like a mask - one that supports a political version of a cinematic star's narration. ${ }^{5}$

The official discourse of the Leviathan, whether as a critical analytic frame or panegyric justification, is a ruse. This "theory of the Leviathan", as Foucault calls it, produces a normative orientation towards the narration of governmentality, one which sustains a celebrity-based "star" narration characteristic of classical Hollywood cinema and its reception, an orientation that continues to dominate extra-cinematic narrative today. This star-based approach to power also structures most academic and media approaches to the presidency, resulting in the personality-based explanations we have grown to expect - and trust. These narrative frames are, in turn, mimicked by the mass media. ${ }^{6}$

The frontispiece from the original 1651 edition of Hobbes's Leviathan provides what Horst Bredekamp has described as "one of the most authoritative answers imaginable to the experience of inescapable chaos and years of civil war" (BREDEKAMP,
2007: 255) ${ }^{7}$ and nicely conveys the protection the Leviathan promises. Further, this interplay of spectatorship and sovereignty is long-standing, as is the often-forgotten temporal dimension of the Leviathan's power that so fascinated Carl Schmitt and fueled his endorsement of the "state of emergency" (which characterized nearly the entirety of Hitler's term of office) and that, as we have seen since 9-11, has become the norm. Even more, the "Cold War", inaugurated during Harry Truman's administration in 1947 with the signing of NSC 68, institutionalized a permanent state of war.

The image of the Leviathan that so impressed Carl Schmitt is clearly a scene of spectatorship. It is also co-constitutive, a sophisticated representation of a pre-cinematic suture, as the spectators themselves make up the figure they are turned toward. We move closer here to an understanding of a "portrait" that is also temporal, the "state of exception" or "emergency" that intrigued Walter Benjamin and Carl Schmitt as they encountered the rise of dictatorships of Mussolini and Hitler. The Leviathan emerges from outside of normal time (and the law). As such, he is decisive: he must be "outside" to act. This may be the appeal of those who have sought to occupy the Oval Office and do so by donning the cloak of the "outsider", a strategy perfected by Ronald Reagan but traceable back to Eisenhower. Truth, as it has been refined by a neoliberal status quo is also, it seems, something the leader, or tyrant, can dispense with, as Stephen Greenblatt has shown in his study of tyranny in Shakespearean drama (GREENBLATT, 2018).

The "outside" from which the Leviathan emerges can be temporal as well: this rupture of normal time is also a quality of the modern Cold 


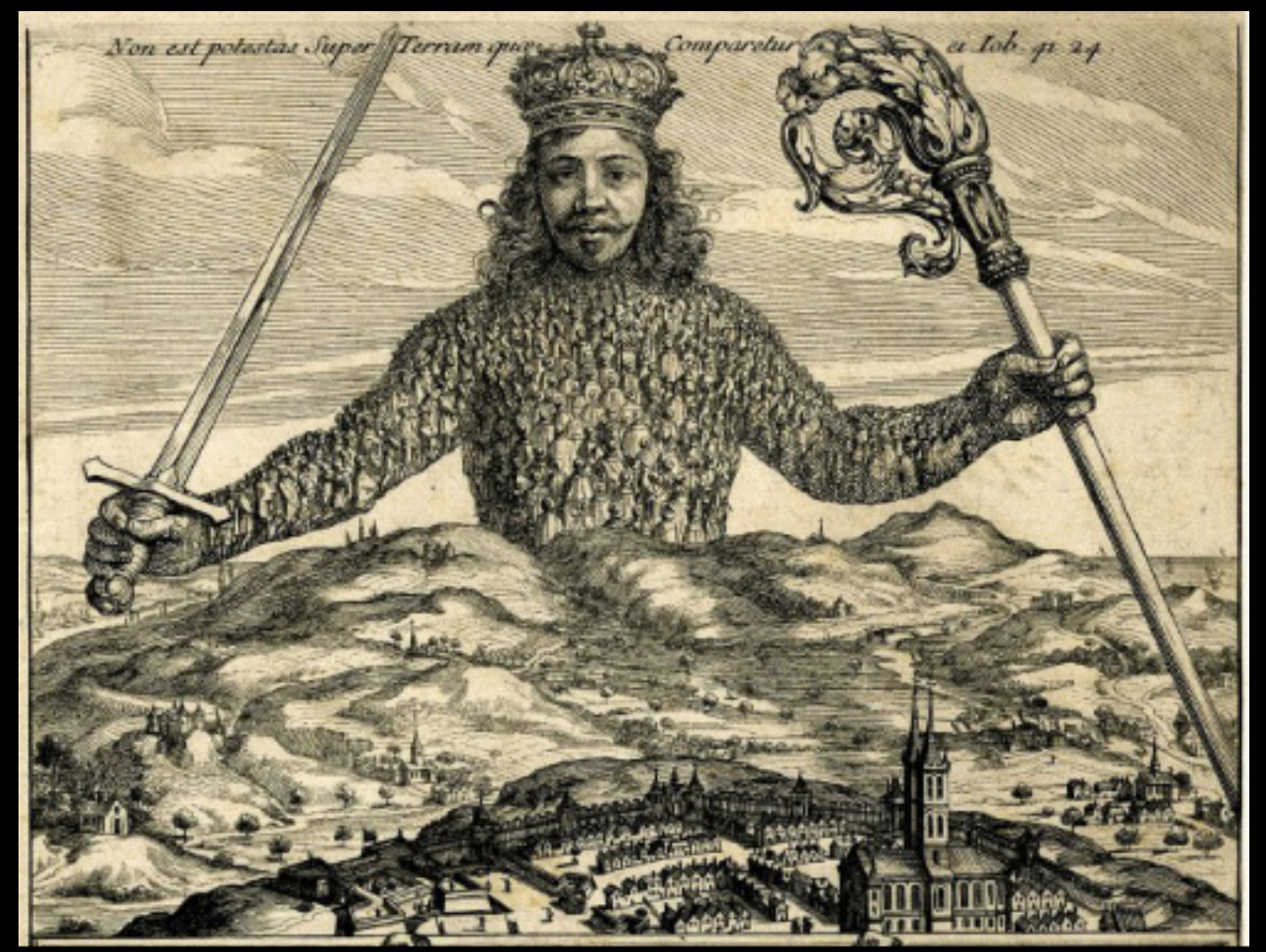

The Leviathan (original frontispiece to the 1651 edition)

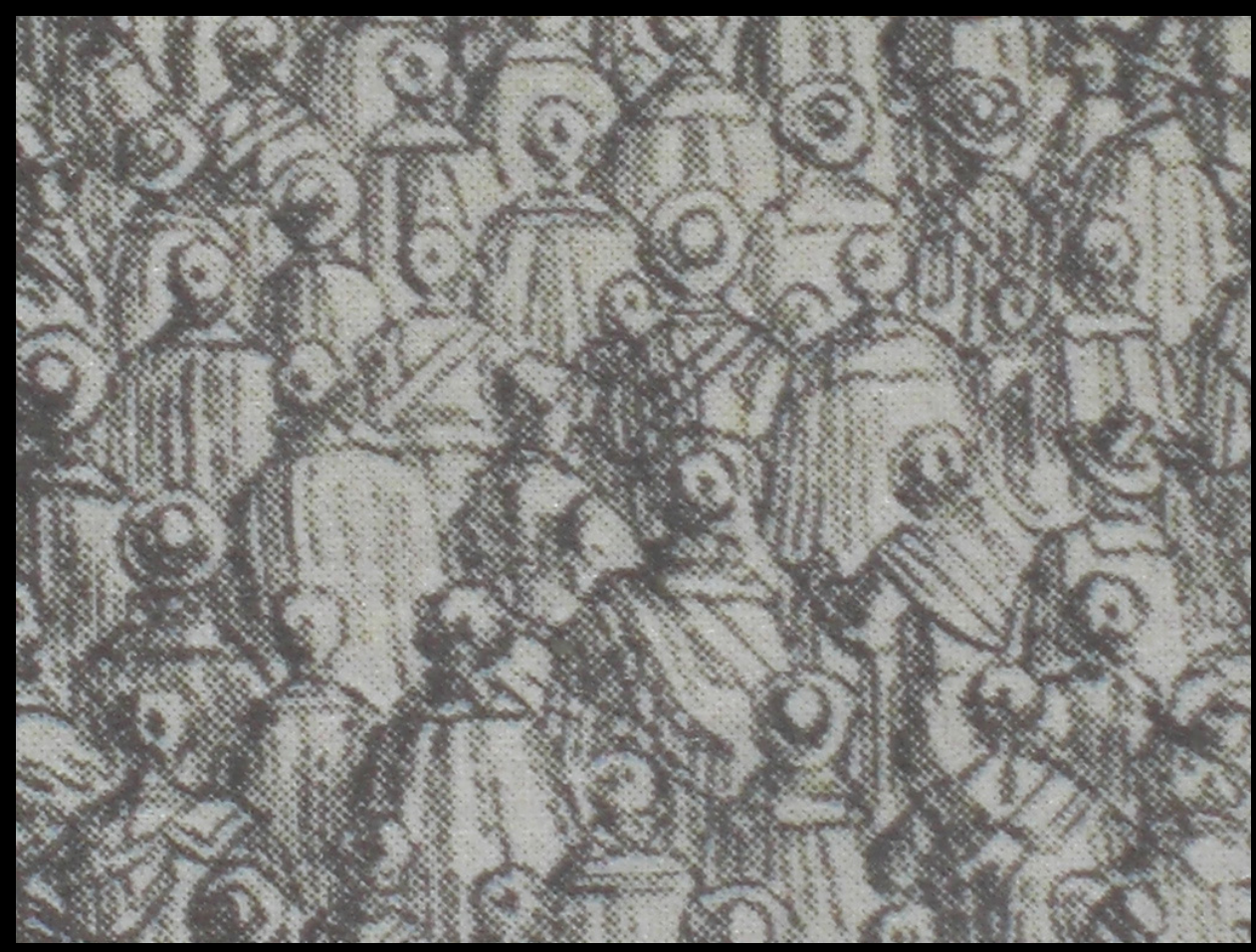

Detail from the original frontispiece of Hobbes's Leviathan: "Society of the Spectacle" 
War presidency, with its massive consolidation of (secretive) power in the nuclear national security state's arsenal of hydrogen bombs and the effective displacement of political participation (in lieu of increased emotional and psychological dependence) in matters of war and peace. "Time" collapses, as it becomes the time of nuclear war, of "duck and cover" and bomb shelters. Yet, in spite of the theory that undergirds the president's authority (to use these weapons because there is not time to consult Congress), time is what the president does not have, although he holds the props of "decision": the "button" or the "football". The dialectic of ignorance and fear that this situation sustains effectively blunts citizens' ability, and even their desire, to participate in a debate about, and take responsibility for, the drastic and ongoing political, economic, and of course military decisions which can, at any moment, be made in their name.

The Leviathan is a transpersonal, trans-temporal figure whose journey from the medieval effigy (which guaranteed sovereign continuity beyond a king's mortality) to the nuclear national security state ends in the eclipse of normal time and, with it, the rule of law and the foundation of popular sovereignty. The modern presidency is co-constitutive with the new time of the Bomb, as the president is presumably the locus of "decision" (as provided in the theory of the Leviathan as a decisive, powerful, leader) for the launching of a nuclear war. The citizen is relegated to the position of a spectator. As Wolin writes of this transitional moment between WWII and the Cold War: "[t]he wartime imaginary [of World War II] was not abandoned after 1945 but recovered as a 'Cold War' between the United States and the Soviet Union. [...] what was abandoned was all talk of participatory democracy." (WOLIN, 2008: 26)
What follows is an analysis of a crisis in representation and in narration at the twinned birth of the modern presidency and the nuclear national security state: Harry Truman, the first Cold War "modern" American president, and the only one to have "used" the atomic bomb, was the transitional figure that provided a glimpse into The Matrix which produces the representation of the decisive president as an effect of power, but not its locus. My claim is that Truman did not "order" or "use" or "drop" the new, horrifying, weapon on Hiroshima (or Nagasaki, but that is a different, but equally grotesque, tale) and that this image was, for a brief period at the end of 1945 until early 1946, destabilized revealing, if only briefly, the abyssal ground of the president's true position.

By examining the liminal moment between the old and new order, between popular sovereignty and its eclipse under the biopolitical pressures of the nuclear national security state and its military-industrial complex, I seek to recover a historical moment which has been lost in the mists of the normative "history" of American presidential power. Put simply, the magnitude of this new technology of death was so extreme that even at this early moment in its "development" (to hydrogen and thermonuclear bombs), the eclipse of democratic control (over the powers of war and peace) has become so overdetermined it has been effectively rendered invisible, popping up on momentarily only to submerge again, as Paul Boyer (1985) has shown in his excellent periodization of public awareness of our nuclear arsenal in the postwar period.

\section{Part II: No More Time: "Man" of the Year 1945}

Time's 1945 cover offers us a potent signpost of the modern presidency and Cold War aesthetics, confirming, 
in its destabilizing transparence, the dislocation of power that comprised its secret foundation.

Two factors are immediately evident: first, that Truman's portrait is a highly conventional one, wholly contained within the red borders of the miniature Time cover, the frame within a frame that indicates its belatedness. Truman is a sign of the past, of, indeed, another temporal order with no impact on the present - the new time of "live" immediacy which had been developing across the past decade with radio and, soon, wide-scale television. Truman does not have any access to this time, while, in contrast, the bomb does: the lightning bolts, fist, and bomb blast composite extend into and beyond the red border of the magazine's "real" cover frame and in depth, violating Truman's miniature frame, an effective graphic representation of the transgressive nature of the weapon as it violated conventional coordinates of space and time. Truman, on the other hand, is rigid, unaware, without energy. On all levels, the bomb is more vibrant and powerful than the man.

The nuclear bomb was dropped on the city of Hiroshima on August 6, 1945. Three days later, another bomb was dropped on the city of Nagasaki (BERNSTEIN, 1977: 1-27). Whatever problems Time had with Truman, it did not overtly question that he had ordered the bomb dropped - and, indeed, the magazine had no access to the top-secret documents necessary to do so - yet everything about the story, like the cover portrait, radically questions the stability of presidential agency and, with it, the stability of the post-war world. The story begins by asking who might be Man of the Year, first eliminating all the great leaders, friend and foe. It reserves a special place for Roosevelt:

"Franklin Roosevelt, Man of 1932, 1934, and 1941, was dead, struck down with dramatic suddenness before he could witness the victory he had charted and planned. Had he lived, 1945 would have been his year - the final flowering of American hope and strength which he had nurtured through the black days made blacker by American indecision. But now he lay in a grave at Hyde Park, mourned by the world" (TIME, 1945).

The Time story conducts its hypothetical search for an adequate replacement for FDR, and, therefore, adequate to the task of harnessing the bomb's power. It returns to Truman, with resignation:

"It was no scientist who, by historic accident, somewhat unwittingly, somewhat against his own will, became more than any other man responsible for the bomb, its use in 1945 and its future. It was an ordinary, uncurious man without any pretensions of any kind, a man of average size and weight, wearing bifocal glasses, fond of plain food, whiskey-\&-water, and lodge meetings. It was Harry Truman, 32nd President of the U.S. (TIME, 1945)

This is a national portrait in crisis. It is an effort to ascribe some coherence, some subjective location (some human location?), to the events of the past months - to define their origin, if you will. While the magazine keeps attempting, again and again, to discern the face of sovereignty - even as it fails - there is a weakening of the force of this paradigm, to the point of near collapse.

"The Man of the Year personified the problem of the year. His very name had almost the force of a pun. Like most of mankind, he was ill prepared for the destiny and the responsibility 


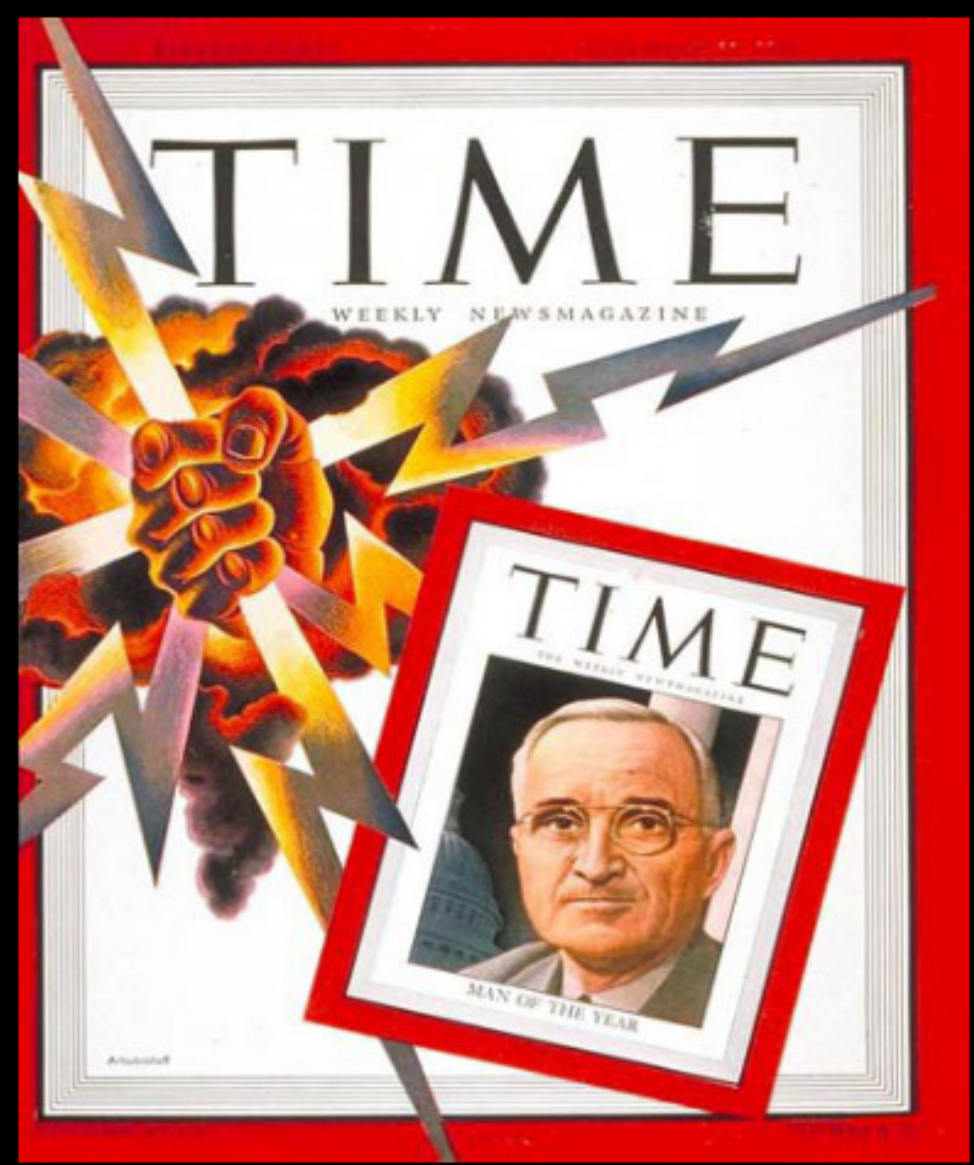

Time Magazine Cover, December 31st 1945

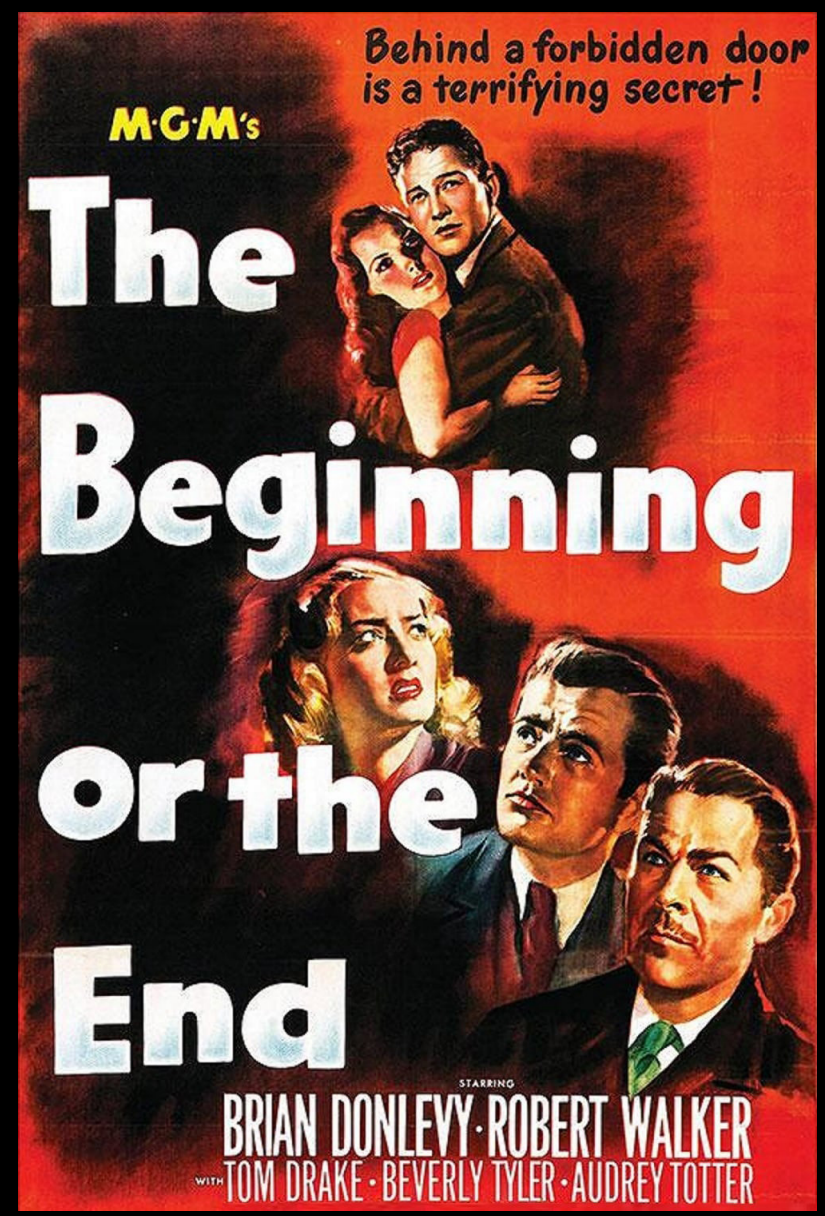


which had been thrust upon him. He did not want the responsibility; the destiny rested awkwardly on his shoulders." (TIME, 1945)

$\mathrm{He}$ is "true man", he is "like most of mankind", an everyman. This designation of an "everyman" reverberates on several levels: it is a sign of his loss of stature (his illegitimacy as a ruler); it conveys, as well, a new flattening of humanity. The "bomb" as a complex network of institutional, psychological, social, and political relays can be viewed as the new Leviathan. While it would take fifteen years for Dwight Eisenhower to say it clearly, the military-industrial complex had placed the bomb as Leviathan: six months into its rule, there are intimations that the bomb has transformed everything, "when it became clear that, from now on to the end of human history, every person would spend his individual life under the threat of [...] collective incineration and extinction which could come at any time, virtually without warning." (SONTAG, 1966: 224)

If we turn now to examine the historical minutae, the actual process which released the first atomic bomb on the city of Hiroshima, we can find, in the declassified documents eventually made public through the Freedom of Information Act, the textual basis of the split portrait and its editorial frame. The editors of Time had gleaned the truth from the zeitgeist, as they marked the transition, not only of one year to the next, but from one epoch to the next. However secret, the emergence of the nuclear bomb on the world stage overshadowed its purported masters. The historical record shows, when read closely, the abyss at the heart of the decision to massacre a city. It is worth examining, as it will provide the explanation for the efforts by the Truman administration to assert their version of the story, to re-institute the
Leviathan. But first we can trace an epistolary trail of breadcrumbs leading to the most powerful release of energy ever seen on earth, a meager trail of hesitation and weakness, allowing the bomb's own identity to took over.

\section{Part III:The Purloined "Order"}

Robert Jay Lifton writes:

"what is especially chastening about the use of atomic bombs against those two Japanese cities is that the military occasion was routine, certainly lacking in any compelling necessity. National survival was in no way at stake. Even the outcome of the war was patently clear, and possibly the atomic bomb achieved no more by way of war goals than saving a few weeks' time. Whatever the appraisal of the Hiroshima decision, there is common ground that it didn't take much for the United States back in 1945 to leap across the nuclear threshold." (LIFTON, 1982: 195)

If we begin with the most spare chronology of this "leap", we are confronted with the disconcerting evidence of an empty throne. How could such a magisterial act not come from a king? The enormity of the shift is inversely matched by the almost indecipherable, minute textual trail this metamorphosis left in its wake: this is its account, the literal and metaphoric trace of the evacuation of authority, of authorship, of decision, by Harry Truman.

On July 7, 1945, Truman leaves by ship for Europe to attend the Potsdam meeting with Churchill and Stalin, arriving in Berlin on July 16, the same day of the successful Trinity Test in New Mexico. On July 21 - five days later - Truman is finally informed of the test. On July 24 , a memo is written authorizing the use of the bomb against 
various targets in Japan. The order is not from the President. On August 2, the President leaves by ship to return to the United States. While he is en route, the city of Hiroshima is bombed. These are, as they say, "just the facts". Yet even the most basic facts - one would presume the easiest facts of all to establish, such as when the order was given by the President of the United States to drop a new, extremely powerful, top-secret weapon - and on whom or what - these facts are as elusive as "presidential authority" suddenly appears to be in these first, tremulous, months after the death of the giant Roosevelt. Investigation of the details now available show the actual process of this transition not only from Roosevelt to Truman (marked enough), but the transition from one regime to another: from democracy to the Cold War nuclear national security state and its new sovereign: the Bomb. A textual trail provides an epistolary confirmation, if you will, of the loss of the author, and the fugitive place of the "author" in the decision to slaughter hundreds of thousands of civilians merits our attention before turning, finally, to examine the clumsy efforts to re-assert presidential "authority" through the ineffective tools of the narrative cinema.

On July 25, 1945, while still struggling with the difficult Potsdam negotiations with Winston Churchill and Joseph Stalin, Truman writes in his journal:

"This weapon is to be used against Japan between now and August 10. I have told the Sec. of War, Mr. Stimson, to use it so that military objectives and soldiers and sailors are the target and not women and children. Even if the Japs are savages, ruthless, merciless and fanatic, we as the leader of the world for the common welfare cannot drop that terrible bomb on the old capital or the new. He and I are in accord. The target will be a purely military one and we will issue a warning statement asking the Japs to surrender [...]" (quoted in FERRELL, 1980: 55-56).

Yet, the day before this journal entry, a top-secret order has been sent to General Carl Spaatz. It is not from (nor does it refer to) Truman but is "issued to you with the approval of the Secretary of War and of the Chief of Staff, USA". What are the details of the bomb order? Is there any mention of Truman's intentions, as indicated in his journal? Is there a directive regarding civilians? Is there a process set up to warn the Japanese? No. The order is written as follows: "The 509 Composite group [...] will deliver its first special bomb as soon as weather will permit visual bombing after about 3 August 1945." There follows a list of four cities, all possible targets (quoted in STIMSON and BUNDY, 1947). The order continues by stating that "additional bombs will be delivered on the above targets as soon as made ready by project staff". It is, in other words, an "order" to drop the bomb and, indeed, multiple bombs, as soon as they are ready, an authorization that has emerged from within belly of the multi-billion dollar Manhattan project, but not from the President.

Nearly a week later, on July 31st, Truman - still in Germany, remember - receives a telegram. It is from Secretary of War Stimson, telling him that General Groves' project (the Manhattan Project) is progressing so fast that they need the President's statement on the dropping of the bomb by August. That is the next day, they need it right away. General Groves' project (the Manhattan Project is not General 
Groves' any more than it is Truman's) is "proceeding faster than expected" the missive reads, breathlessly. We sense a reference to some kind of entity, some agency, something proceeding, speeding up, out of control. Is there any doubt as to the sovereign autonomy of the Bomb here, the autonomy of the two-billion-dollar Manhattan Project that preceded Truman by five years (and kept secret from him even after becoming president)? This "project", which has occupied every component of the government, has done so in secret, and it is this entity that now asserts its authority - its speed. Things are moving fast, we must stay with the text, such as it is, with language, now almost lost beneath the crushing weight of a new temporality.

Truman has, it appears, earlier approved a statement to be released when the Bomb is used. It is worth repeating, for this history is a muddy textual morass, that this statement was not the order itself, but the presidential explanation to be conveyed to the public in the aftermath of the Bomb's use. Yet, from Stimson's telegram we see that it has been revised. He's not sure he can let Truman see the revised statement: "I will appreciate your authority to have White House release revised statement [recall, not yet seen by Truman] as soon as necessary." He closes with this apology: "Sorry circumstances seem to require this emergency action." There is a transfer of authority. Stimson will "appreciate [Truman's] authority". The revised statement, not seen by Truman, will be released as soon as "necessary". Truman's reply to Stimson is telegraphic, even for a telegram. Yet the breathlessness of all of this rushed, half-articulated pseudocommunication has no cause: there is no impending attack, invasion or any other factor calling for this kind of (emergency) speed, yet Truman's response to Stimson is a hastily written note on both sides of the original telegram: there is not a new telegram, not a dictated message to his secretary, as a text its status is a partial trail of breadcrumbs, less than a post-card, a bit more than a shopping list. "See over" is scribbled on the front side of Stimson's telegram, and on the other side is scrawled, as if in great haste: "Sec. War. Reply to your 41011 suggestions approved Release when ready but not sooner than August 2. HST."

Let us step back for a moment and consider what is happening here: the President has at some point earlier approved a statement, or, no, he has approved the release of a statement "by" him - but which he has not read. The approval of the release of the statement is also understood by Stimson to be a simultaneous open-ended approval of the Bomb's deployment, in complete contrast to Truman's own carefully described parameters in his journal. It must be noted, as well, that the horrific new weapon does not merit any proper reference: it is literally absent from the sentence, "Release when ready..." It is clearly the driving force of events, yet cannot be named.

The "release" of the statement will take place after the "release" of the bomb. General Groves' project, the Bomb, is, well, in a hurry. It appears that the determination regarding when this weapon will be used is governed by when it will be completed - it is internal to the mechanism - the Bomb - and its institutional support the Manhattan Project, "General Groves' project" - but soon to be transformed into the nuclear national security state, not governed from without, by executive authority, popular sovereignty - democracy. The fugitive nature of this "decision" is indicated in this telegraphic and 
partial text, which refuses complete sentences or even a full signature. The illusion of presidential power in regard to the Bomb: this will all become later. There is not (yet) the apparatus to simulate control, such as the "button" (his "finger on the button") which is also represented by the briefcase or "football" containing launch codes which is carried by a special agent who follows the president everywhere. What we see here - and it is barely visible, nestled in Truman's presidential archives, there for all to see but, like Edgar Allan Poe's purloined letter, unnoticed, is merely the trace of a massive, multi-layered shift occurring from democracy to the Cold War military industrial complex and what Sheldon Wolin names "inverted totalitarianism" (2008).

Truman then receives a letter from Stimson, delivered by courier. Truman will be presented with the revisioned statement (and no mention of his editing this...). There is still no date, no target, none of the usual signs of decision; rather, Stimson writes again about the lack of time:

"Attached are two copies of the [revised] statement which has been prepared for release by you as soon as the new weapon is used [...] The reason for the haste is that I was informed only yesterday that, weather permitting, it is likely that the weapon will be used as early as August 1, Pacific Ocean Time, which as you know is a good many hours ahead of Washington time." (STIMSON, 1945: 181).

This time, Stimson reminds Truman of global time. But there is no conventional time in this new time of the Bomb: the mechanism of decision is sweeping past both men "responsible" for the use of this weapon; the bomb might be ready by August 1, Pacific Ocean Time - indeed, many hours ahead of Washington time. Though the one thing Truman has managed to clearly direct on his scribbled note is that the bomb should not be dropped before August 2, Stimson seems to have been unable to read even this tiny incursion of Truman's agency. Yet this is not a story of insubordination: Stimson and Truman are not protagonists here, but rather props.

\section{Part IV: The failed re-assertion of the Presidential Auteur: The Beginning or the End}

Released in February of 1947, the film The Beginning or the End is the first of only three films made over a fifty-year period about the use of nuclear weapons against Japan. ${ }^{8}$ It is the only one which portrays a sitting president: akin to both newsreel and biopic, even its title displays its confused temporality. The film is a potent and rare example of the kind of propaganda usually associated with totalitarian regimes: to change representation one thereby changes history. The narrative being enforced is that of the decisive president, the locus of power in this (new) nuclear age: that Truman made... a decision, he is the author, of this... with all that it entails. As we have seen, his literal authorship was eclipsed and subverted on the textual field of notes and telegrams; his figurative authorship, the master of the national narrative, was also at stake. The gap that Time's editors discerned in the zeitgeist of this extraordinary watershed in American (and world) history had to be "repaired".

The first in-depth exploration of this film was conducted by Robert Jay Lifton (1982), one of America's fiercest and most prolific critics of the nuclear national security state and the "genocidal mentality" which it spawned. The film was inspired by a letter sent to Donna Reed by one of the scientists who had worked on the 
Manhattan Project; its message was that it would have been better to lose even a half million lives than unleash atomic energy on the world. Hollywood was not necessarily the wrong place for them to turn, as the "social problem film" was still considered a viable post-war genre, and we can trace its movement from inception to completion along these lines.

MGM began the process of constructing this film by soliciting advice from these scientists and gave General Groves and the White House script approval. The film's initial purpose, as much as it can be surmised from the extant records, was to provide a sympathetic account of what journalist Walter Lippman called the "activist scientists" such as Szilard and Oppenheimer. Its narrative followed a young scientist who is ambivalent about the use of the weapon on Hiroshima yet ends up dying of radiation exposure while arming the weapon. Despite this rather downbeat narrative arc, the film manages, in the end (and after numerous revisions by Groves), to be very upbeat about the use of the weapon (never mentioning the second bomb, which was dropped on Nagasaki without any "order" from Truman).

My specific interest here is to look at this rare visualization of Truman "deciding" to drop the bomb, a small part of the original version of the film that had been approved by the White House. In this original version, Groves and Stimson inform Truman about the bomb after FDR's death, and Truman appears to make a "snap judgment" about its future use. A select preview audience (including Walter Lippman) was shocked by this portrayal. Truman's secretary complained about the scene, which had been approved by Truman. But Walter Lippman, an exemplary spectator with "access", would say of the scene that it reduced the role of the president

"to extreme frivolity in a great matter. Serious people abroad are bound to say that if that is the way we made that kind of a decision, we are not to be trusted with such a powerful weapon. As you know, the decision was not made that way." (LIFTON and MITCHELL, 1995: 363)

Assistant Secretary of War John McCloy responded by asserting that "such a misrepresentation would greatly complicate some of the thinking which is now current about the bomb" (LIFTON and MITCHELL, 1995: 363).

In response, MGM immediately set out to re-write and then re-shoot it. The new version was set in Potsdam, replete with the expected trappings of power (mise-en-scène, the backdrop of Potsdam agreement, that text which was Truman's inaugural encounter with history; a heavy-handed discursiveness to "explain" the bombing), and staged an extended exchange between Truman and his secretary, Charles Ross, ending with this dialogue:

Ross: As President of the United States, sir, you could make no other decision.

Truman: As President, I could not. So I have instructed the Army to take the bomb to the Marianas and - when they get the green light - to use it. (LIFTON and MITCHELL, 1995: 364)

Lippman's extreme discomfort over the representation of Truman's "decision" caused the White House to re-think the narrative arc of the president's portrayal and was an important factor in the reconsideration of the actor who played him. The original actor, Roman Bohnen, was deemed "not military enough" in demeanor, and a new actor, Art Baker, was chosen to replace him. All of this is, perhaps, in retrospect self-evidently comical and transparently useless. 
Yet it is this logic, the logic of the Leviathan's locus in the president, in the man, that governs all subsequent evaluative models of the presidency to this day.

\section{Conclusion}

What we see in this account is that the film didn't matter: the effort to re-insert an "auteur", an author, confidently in control of the narrative, is clumsy and ineffective, a perfect example of Truman (and his representatives) misreading the portrait of the Leviathan, if you will - the nuclear Leviathan has left them far behind. The momentary instability of Truman's portrait shows us with uncanny accuracy the crypt, which would seal this and all future presidents within its self-perpetuating apparatus. The listless, static, and hopeless President portrayed on the 1945 Time "Man of the Year" cover was a sign (however fleeting) of the scale of the dislocation of power that occurred under the auspices of a war that was also not a war, a permanent "state of exception": the Cold War.

This brief exposure of the absence of presidential control, however, would prove to be one of the final times it would be so dramatically evident. Since then, and beginning with the re-casting of Truman's own portrait as his presidency continued, the Cold War power apparatus has worked assiduously to reinscribe the myth of presidential agency as the locus of the
American Leviathan on the popular imagination. The proliferation of media technology since the end of World War II has served to reinforce the mask, to refine and burnish the portrait rather than to illuminate the reality behind it.

This continuing effort reached its culmination in the figure of Ronald Reagan. The widespread acceptance of such a self-evident cipher as the symbol of strength and decisiveness ensured that such a glimpse of the absent face/place of power would never occur again. The portrait and body of the president as the Leviathan's decisive enforcer of order and stability was firmly in place. The fact that the attempt on Reagan's life in 1981 served to provide not another revelation of this massive dislocation of power, but rather to solidify the image of the president's character as the source of power and authority, underscores this point.

In light of our current situation and the extreme and (intentionally?) unstable personality that composes the presidential portrait of Donald Trump, we may do well to remember that the underlying truth has not changed. The apparatus that is the trans-personal, trans-temporal locus of power has not changed, and fixing our focus on the mask, on the particulars of the individual, either by idolizing or demonizing him, may serve only to distract us from the power structure we really need to understand.

\footnotetext{
Acknowledgements

I would like to thank my editor and friend Brigham Taylor, as well as the Comparative Cinema editors, for their invaluable assistance completing this manuscript.
} 
2/ NSC 68 was a document of over sixty pages of recommendations by the National Security Council to President Truman. Sheldon Wolin's stunning new history of the Cold War details how shocking this shift was. Cf. pp. 27-35, for starts. At its heart is the establishment of an even larger, and more secret, national security apparatus and intensification of the nuclear weapons program.

3/ See Michel Foucault's work on governmentality and the Leviathan, which forms the basis of this work: in particular Society Must Be Defended. Santner offers a fascinating analysis of the tension produced by the "royal remains" of sovereignty (the flesh of the sovereign as it is translated to the "body politic" in The Royal Remains: The People's Two Bodies and the Endgames of Sovereignty [SANTNER, 2011]). See also Derrida's The Beast and the Sovereign (DERRIDA, 2017) which explores the connects between animality and sovereignty.

4/ This legitimization occurs through what Foucault describes as the "juridical" theory of power: "In the case of the classical juridical theory of power, power is regarded as a right which can be possessed in the way one possesses a commodity." (FOUCAULT, 2003: 13)

5/ See Hans Belting's fascinating recent study of the face and, in particular, the transformation of the "public" face in the U.S. by Henry Luce, owner of Time and Life. Belting writes in regard to Life's display of faces on its cover that "the layout of the magazine conveys the impression that the news and its bonus of topicality are responsible when a medium (itself faceless) attracts ever-new faces to it - faces that continually replace one another as masks." (BELTING, 2017: 178)

6/ Just a sample would include Richard Neustadt (on presidential power), Arthur Schlesinger Jr. (on excessive presidential power) and Kathleen Hall Jamieson (on the "advertising" of presidents).

7/ He is referring to the 1648 Treaty of Westphalia formalizing the end to the Thirty Years' War, which was brought on by weak nation-states and religious enmity. Hobbes's treatise on the Leviathan, written three years later, provides the figure of a powerful leader which ends war through the monopolization of violence.

8/ The other two are: Above and Beyond (Melvin Frank, 1952) about Col. Tibbets, the pilot who dropped the first bomb on Hiroshima, and Fat Man and Little Boy (Roland Joffé, 1989): like The Beginning or the End, the latter spends most of its screen time on the Manhattan Project, and ends with the detonation of the first bomb in the Trinity test. The presidential decision is off-screen, the drama is in the scientists development of the weapon.

\section{Bibliography}

AGAMBEN, Giorgio (2011). The Kingdom and the Glory. Redwood City, CA: Stanford University.

BELTING, Hans (2017). Face and Mask: A Double History. Princeton, NJ: Princeton UP.

BERNSTEIN, Barton (1977). The Perils and Politics of Surrender: Ending the War with Japan and Avoiding the Third Atomic Bomb. Pacific Historical Review, 46, p. 1-27.

BOYER, Paul (1985). By the Bomb's Early Light. New York, New York: Pantheon.

BREDEKAMP, Horst (2007). Thomas Hobbes's Visual Strategies. SPRINGBORG, Patricia (ed.), The Cambridge Companion to Hobbes's Leviathan (p. 29-60). Cambridge, UK: Cambridge UP.

BRODERICK, Mick (2010). "The Buck Stops Here": Hiroshima Revisionism in 
the Truman Years. JACOBS, Robert (ed.), Filling the Hole in the Nuclear Future: Art and Popular Culture in Response to the Bomb (p.135-158). Lanham, MD: Lexington Books/Rowman \& Littlefield.

DEBORD, Guy (1983). Society of the Spectacle. Detroit: Black and Red.

DERRIDA, Jacques (2017). The Beast and the Sovereign. Chicago:

University of Chicago Press.

DOANE, Mary Anne (2001). Information, Crisis, Catastrophe. LANDY, Marcia (ed.), The Historical Film: History and Memory in Media (p.269-285). New Brunswick, NJ: Rutgers UP.

FOUCAULT, Michel (2003). Society Must Be Defended: Lectures at the College De France 1975-1976. New York: Picador.

FREUD, Sigmund (1899). Screen Memories. FREUD, Sigmund; STRACHY, James; FREUD, Anna (1966), The Standard Edition of the Complete Psychological Works of Sigmund Freud, 3 (p.301-322). London: The Hogarth Press.

GREEENBLATT, Stephen (2018). Tyrant: Shakespeare on Politics. New York: WW Norton.

LIFTON, Robert Jay; FALK, Richard (1982). Indefensible Weapons: The Political and Psychological Case Against Nuclearism. New York: Basic Books.

LIFTON, Robert Jay; MITCHELL, Greg J. (1995). Hiroshima in America. New York: Harper Perennial.

PRINGLE, Peter; ARKIN, William (1983). SIOP: The Secret US Plan for Nuclear War. New York: WW Norton.

SONTAG, Susan (1966). The Imagination of Disaster. SONTAG, Susan (1966), Against Interpretation (p. 224-244). New York: Dell.

SANTNER, Eric (2011). The Royal Remains: The People's Two Bodies and the Endgames of Sovereignty. Chicago: University of Chicago Press.

STIMSON, Henry L. (1945). Document 27, Papers of Harry S. Truman. Letter to President Truman, from Henry L. Stimson, July 31, 1945. President's Secretaries Files.

STIMSON, Henry L; BUNDY, McGeorge (1947). On Active Service in Peace and War. New York: Harper and Brothers.

TIME (1945). The Bomb and the Man. Time, 31st December 1945. Retrieved from: http://www.time.come/time/magazine/printout//0,88816,886699,00. html [access: 8th September 2006]

TRUMAN, Harry S; FERRELL, Robert H. (1980). Off the Record: The Private Papers of Harry S. Truman. New York: Harper and Row.

VIRILIO, Paul (1990). Popular Defense and Ecological Struggle. New York: Semiotexte.

WOLIN, Sheldon S. (2008). Democracy Incorporated: Managed Democracy and the Specter of Inverted Totalitarianism. Princeton, NJ: Princeton UP.

How to quote FREDA, Isabelle (2019). Screening Power: Harry Truman and the Nuclear Leviathan. Comparative Cinema, Vol. VII, No. 12, pp. 3852. DOI: 10.31009/cc.2019.v7.112.03 